\title{
A Study on Online EFL Instructors' Teaching Satisfaction during Pandemic
}

\author{
Esra ECE *1 (iD) Semin KAZAZOĞLU2 ${ }^{2}$ (D) \\ ${ }^{1}$ İstanbul Bilgi University, İstanbul, Turkey, esra.ece@bilgi.edu.tr \\ ${ }^{2}$ Yıldız Technical University, İstanbul, Turkey, semink@yildiz.edu.tr \\ * Corresponding Author: esra.ece@bilgi.edu.tr
}

\begin{tabular}{|c|c|}
\hline Article Info & Abstract \\
\hline & $\begin{array}{l}\text { In 2020, institutions had to shift to online education because of the } \\
\text { health issues raised globally. Since online education is a complex } \\
\text { process, the needs and expectations of instructors also show }\end{array}$ \\
\hline Received: 1 November 2021 & differences. However, the number of studies focused on English \\
\hline Accepted: 11 December 2021 & $\begin{array}{l}\text { language instructors' job satisfaction is limited. Therefore, this study } \\
\text { aims to find out online instructors' job satisfaction related to gender, } \\
\text { years of teaching experience and the highest educational degree }\end{array}$ \\
\hline $\begin{array}{l}\text { Keywords: Online education, EFL } \\
\text { instructors, online job satisfaction }\end{array}$ & $\begin{array}{l}\text { (bachelor, master's, and doctorate) variables. The sample consists of } \\
218 \text { participants who were selected according to purposive }\end{array}$ \\
\hline & sampling. This study has a quantitative research design. \\
\hline doi $10.18009 /$ jcer.1017362 & $\begin{array}{l}\text { Accordingly, "The Online Instructor Satisfaction Measure-OISM" } \\
\text { developed by Bolliger et al. (2014) was used to collect quantitative } \\
\text { data. Additionally, factor analysis, internal consistency reliability } \\
\text { and normality tests, independent sample t-test, and one-way }\end{array}$ \\
\hline Publication Language: English & $\begin{array}{l}\text { ANOVA tests were conducted for data analysis. The findings } \\
\text { revealed that the mean level of online instructors' job satisfaction } \\
\text { was } 89.04 \text {. Besides, there were some differences related to gender } \\
\text { and the highest educational degree in subscale level. }\end{array}$ \\
\hline
\end{tabular}

open access (

To cite this article: Ece, E., \& Kazazoğlu, S. (2021). A study on online EFL instructors' teaching satisfaction during pandemic. Journal of Computer and Education Research, 9 (18), 1084-1097. DOI: $10.18009 /$ jcer.1017362

\section{Introduction}

The CoronaVirus (Covid19) outbreak occurred in December 2019, and later, The World Health Organization (WHO) defined it as a global pandemic (WHO, 2020). Many countries, including Turkey, had to take precautions to prevent the virus from spreading; therefore, they set strict rules such as lockdowns and social distancing protocols. The precautions also applied for the educational institutions, and they had to conduct educational operations online.

Online education is a type of distance education that delivers course content via Internet-based platforms (Kentnor, 2015, p. 22). It has some advantages since it is flexible, interactive, and convenient (Smedley, 2010). The Online Learning Consortium established criteria for quality in online education (The 5 Pillars: Online Learning Consortium Quality 
Framework, 2015). The framework's principles, also called pillars, are learning effectiveness, cost-effectiveness and institutional commitment, access, faculty satisfaction, and student satisfaction. Faculty satisfaction is one of the five pillars of online education's quality, together with student satisfaction, learning effectiveness, access, and institutional costeffectiveness (Sloan Consortium, 2002).

Nevertheless, when online education became an obligation rather than an option, instructors were not ready and engaged in a well-planned online education context (Bozkurt \& Sharma, 2020). Even though some institutions had already started to provide some online courses as a part of their educational programs before the pandemic, the majority of the instructors had not experienced teaching online before. One of the biggest challenges was the adaptation of instructors who were used to teaching face-to-face. It required using new approaches and adjusting teaching habits acquired in a traditional face-to-face teaching context. Thus, all those changes caused extra workload for the instructors (Sanje \& Varnal1, 2014). Extra workload and intensive working hours were some examples of typical challenges that come from the transition period between online and face-to-face (Gay, 2016). The faculty members stated that they needed to spend more time in online teaching (Gazza, 2017). For instance, online instructors had to spend more time and have higher self-efficacy to deal with students' emotional states like isolation and feeling invisible (Reilly et al., 2012).

As a result, job satisfaction became an issue to be investigated within the online education framework, as well. When literature is reviewed, the number of articles on "faculty satisfaction" is considerably fewer than "student satisfaction" within the online teaching scope (Berbegal-Mirabent, Mas-Machuca \& Marimon, 2018). As instructors are the backbone of education and job satisfaction is a complex concept to be discussed, this study aimed to investigate online English instructors' job satisfaction in relation to gender, years of experience, and the highest degree variables.

\section{Literature Review}

\section{Theoretical Framework}

Herzberg's Motivation/Hygiene Theory is the pillar of the theoretical framework of this study. This theory was founded by Herzberg et al. (1959), and it classifies the encouraging factors as motivators and hygiene factors related to dissatisfaction factors. Dissatisfaction does not mean the opposite of satisfaction even though they are related (Herzberg, 1987). Motivators are observed as intrinsic factors increasing job satisfaction, but 
they do not compulsorily decrease satisfaction when absent (Herzberg et al., 1959). On the contrary, hygiene factors decrease the satisfaction level, but they do not necessarily increase it. This theory suggests that an employee's job satisfaction cannot be increased by only reforming the hygiene factors. To ensure permanent and long-term raised job satisfaction, a leader needs to provide motivator factors. Later, Hagedorn (2000) suggested another theory that claims that some factors trigger faculty satisfaction. Trigger theory recognizes each factor, which can be about emotional stages and family issues, as an opportunity to raise or lower faculty satisfaction. This theory also admits that each factor influences faculty satisfaction in higher education. In addition to Herzberg et al.'s hygiene and motivator mediators, trigger theory also includes demographics and environmental conditions as three mediators of the conceptual model of faculty satisfaction.

\section{Job Satisfaction}

Chamberlain et al. (2016) defined job satisfaction as a combination of individuals' selfevaluations of task performance, emotions, and values they attribute to a job. Hongying (2007) suggested that teaching, administration, and school quality have a direct point to satisfaction. Instructor satisfaction was described as "teachers' overall attitude and views toward their working conditions and profession" (p.11).

Demographics are role players of satisfaction in higher education (Bullers, 1999). Some variables affecting job satisfaction are age, education level, work experience, and emotional state (Dodd-McCue \& Wright, 1996). However, the variables of job satisfaction have also been examined from other perspectives. For example, reward is found to have a positive effect on private junior high school teachers' job satisfaction (Hardianto et al., 2019). Another recent educational study on teachers' performance indicated that transformational leadership and creativity have a direct impact on vocational high school teachers' job satisfaction (Ripki et al., 2020).

In a study of educational organizations, the predictors of instructors' job satisfaction were listed, and gender was detected as the most common predictor variable leading to age, organizational capacity, and years of experience (Thompson et al., 1997). On the other hand, bad management, high-stress level, low control level, and not being an active decision-maker are related to decreasing job satisfaction levels (Bogg \& Cooper, 1994). Several studies have concluded that older and tenured professors are the faculty members with the highest level of overall satisfaction (Hagedorn, 2000). Some demographic studies showed that female 
teachers were more satisfied with their jobs than males (Bogler, 2005). Murray and Cunningham conducted a study (2004) and examined 45 faculty members from seven different colleges for job satisfaction. It was revealed that the majority of the faculty thought that students were the primary source of their job satisfaction. This study also analyzed the gender impact, and it was found that the job satisfaction of female faculty members was related to their relationships with students while male faculty members were more satisfied with students' accomplishments. Being a mentor to a person rather than a student as a future employee for the female faculty was more fulfilling.

Howe et al. (2018) did not find a significant difference based on years of experience in a face-to-face teaching environment, but they observed a remarkable change in job satisfaction and the years of online teaching experiences. Faculty members who taught more than 20 fully online courses were reported with higher satisfaction levels. Similarly, Kennedy (2015) carried out a study about online teaching satisfaction and found out that there was a positive relationship between years of online teaching experience and online job satisfaction. Arbaugh et al. (2001) also found the teaching experience as the most influential factor on job satisfaction.

According to the results of a study conducted by Ulmer et al. (2007), online teaching experience was an influential factor of perceptions of faculty members on the value of distance education. Also, this study revealed that experienced instructors had a more positive view of distance education about instructor-to-student interaction. Kuo et al. (2014) found that student-to-student and instructor-to-student interaction patterns were the most influential factors of satisfaction in the online education environment. Another study in Indonesia explored the relationship between demographics, job characteristics, and career development and the findings revealed that those elements were directly linked to the job satisfaction of instructors (Daryanto, 2014).

As a very recent study, Topchyan and Woehler (2021) explored the association of gender, years of teaching experience, and faculty status with job satisfaction, and some differences were found related to gender and faculty status. Results indicated that female teachers were more engaged with student interaction and full-time faculty members had a higher job satisfaction level while the duration of teaching experience was not directly correlated with job satisfaction. 


\section{Purpose of the Study}

The purpose of the present study is to examine English language instructors' job satisfaction by analyzing the relationship between online instructor job satisfaction and the following independent variables:

1. gender

2. years of teaching English experience - traditional and online education

3. the educational background

\section{Method}

\section{Research Design}

In this study, quantitative research design was used to analyze the correlation among variables (Gall, Gall \& Borg, 2007). Furthermore, the survey design was used, which is mainly suggested as data collection instruments consisting of questionnaires.

\section{Participants}

As the sampling technique, non-probability sampling was used. This sampling method has a procedure through which the researcher chooses a sample based on research purpose, subject availability, or other non-statistical criteria (Guo \& Hussey, 2004). For the quantitative research, purposive sampling was used, which is a type of non-probability sampling method. Purposive sampling technique can be explained as "a systematic, nonprobabilistic approach to sampling is taken by purposively selecting participants who have: The appropriate experiences and knowledge; the capability to reflect and articulate; an understanding of the subject; time to be asked, and are prepared to participate" (Creswell, 2014, p. 189).

The participants were instructors who teach in universities' English preparatory classes, teaching online English courses. Therefore, they were English instructors who worked in higher education in Turkey. Each instructor was invited to contribute to the study via email. A standard email was written to reach instructors from different universities in Turkey, and it was sent to instructors' emails after checking online English classes in their universities. Approximately, 600 emails were sent. In total, 218 participants took part in the study. When demographic distribution was analyzed, it was seen that $77.5 \%$ of the participants were females, and $22.5 \%$ were males. $33.8 \%$ had bachelor's degrees, $59.2 \%$ had master's degrees, and $7 \%$ held a doctorate. 


\section{Data Collection}

The Survey

It consisted of three parts: 6 questions for demographics and 27 items of the adapted version of "The Online Instructor Satisfaction Measure - OISM" (Bolliger et al., 2014). The survey was created on an online platform because all the universities were working online. For this, "Google Forms" was used because of its easy access and user-friendly interface.

The OISM is a validated tool to measure faculty satisfaction in online teaching. It consists of five categories dealing with online instructor satisfaction:

- Instructor-to-Student Interaction: Communication between instructors and students throughout the course

- Student-to-Student Interaction: Communication and collaboration among students for supporting each other and participation in course

- Affordances: Access to various instructional resources. Having convenience and flexibility thanks to the nature of online teaching

- Institutional Support: Support provided by the institution to develop and deliver the courses.

- Online Course Design, Development, and Teaching: Course design, preparation, and delivery. It includes learning objectives and online assessment.

The first factor was found as "Student to Student Interaction. The second factor was "Institutional Support." The fourth factor was "Instructor-to-Student Interaction." The fifth factor was "Course Design/Development/ Teaching."

Table 1. Reliability of the scale

\begin{tabular}{lll}
\hline Subscale & No. of Items & Cronbach Alpha \\
\hline OISM & 27 & .870 \\
Student to Student Interaction & 5 & .757 \\
Institutional Support & 6 & .848 \\
Affordances & 5 & .786 \\
Instructor-to-Student Interaction & 6 & .734 \\
Course Design/Development/Teaching & 5 & .786 \\
\hline
\end{tabular}

The Cronbach's Alpha value of .870 appeared to be quite reliable. Thus, it was seen that the sum of the scale provided an acceptable degree of reliability. First, the preparatory classes in the universities were checked, and a list was created. The instructors who teach in English preparatory courses were listed. They were sent an explanatory email informing the 
researcher's background, the aim of the study, and the survey procedure to request their participation. At the beginning of the survey link, there was information about the study background and parts of the survey. To continue to respond to the survey, participants needed to read the information and complete the consent form. As the prerequisite of participation in the survey, the first question was teaching fully online courses or not. In the participant background part, whether teaching fully online courses or not, gender, age, the obtained highest degree, faculty status at the institution, the type of the institution (state or private), years of experience, the duration of online teaching experience and the type of online course they taught were asked.

\section{Data Analysis}

The quantitative data were analyzed via SPSS 25.0 software. The outlier values were excluded from the dataset, and parametric tests were chosen. First of all, the normality distribution was checked by analyzing Kurtosis-Skewness coefficient values. To determine to use parametric or non-parametric tests with the obtained data from the survey, normality tests were conducted. The reliability and validity of the data collection tools were analyzed. There was a normal distribution between the participants' gender, the highest degree, years of online teaching experience, online job satisfaction, and the subscales' scores, so an independent t-test was used.

\section{Findings}

The average score of online instructor job satisfaction was found as medium ( $\mathrm{x}=$ 89.04) among the participants of the study. The relationship between gender, the highest degree, and years of teaching experience were analyzed, and the results were presented.

Table 2. Gender differences in the online instructor satisfaction

\begin{tabular}{|c|c|c|c|c|c|c|c|}
\hline & Gender & $\mathbf{N}$ & Mean & Std Deviation & $\mathbf{t}$ & df & $\mathbf{p}$ \\
\hline \multirow[t]{2}{*}{ Instructor to Student Interaction } & Male & 48 & 3.13 & 0.54 & 2,149 & 211 & ${ }^{*} 0.033$ \\
\hline & Female & 165 & 2.96 & 0.47 & & & \\
\hline \multirow[t]{2}{*}{ Affordances } & Male & 48 & 3.76 & 0.85 & 1,212 & 211 & 0.227 \\
\hline & Female & 165 & 3.60 & 0.77 & & & \\
\hline \multirow[t]{2}{*}{ Institutional Support } & Male & 48 & 3.39 & 0.96 & 0.401 & 211 & 0.689 \\
\hline & Female & 165 & 3.33 & 0.85 & & & \\
\hline
\end{tabular}




$\begin{array}{lllllllll}\text { Student to Student Interaction } & \text { Male } & 48 & 2.89 & 0.84 & -0.758 & 211 & 0.449 \\ & \text { Female } & 165 & 2.98 & 0.73 & & & \\ \text { Course Design } & \text { Male } & 48 & 3.61 & 0.64 & 0.189 & 211 & 0.85 \\ & \text { Female } & 165 & 3.59 & 0.58 & & & \\ & \text { Male } & 48 & 3.35 & 0.57 & 0.795 & 211 & 0.428 \\ \text { OISM } & \text { Female } & 165 & 3.28 & 0.49 & & & \\ & & & & & & & & \end{array}$

${ }^{*} \mathrm{p}<.05$

An independent sample t-test was conducted to determine whether the participants' levels of job satisfaction and the subscales differed according to their genders. The data revealed that there was a statistically significant difference between genders in terms of Instructor-to Student Interaction $(\mathrm{t}=2.15, \mathrm{p}=.04, \mathrm{p}<.05)$. While the mean score of female participants' satisfaction with instructor-student interaction is 2.96, the mean score of male participants' satisfaction with instructor-student interaction is 3.13. According to the results, males showed a more positive attitude of satisfaction from the instructor to student interaction than females.

The difference between the participants' Affordances, Institutional Support, Student to Student Interaction, Course Design, and OISM participation levels according to their gender was not statistically significant $(\mathrm{p}>05)$.

Table 3. The years of teaching English and online instructor job satisfaction

\begin{tabular}{|c|c|c|c|c|c|c|}
\hline & Teaching & $\mathbf{N}$ & Mean & $\begin{array}{l}\text { Std. } \\
\text { Deviation }\end{array}$ & $\mathbf{F}$ & $\mathrm{p}$ \\
\hline \multirow[t]{4}{*}{ Instructor to Student Interaction } & $1-3$ years & 11 & 2,80 & 0,44 & 2,337 & 0,075 \\
\hline & $4-10$ years & 73 & 2,90 & 0,48 & & \\
\hline & $11-16$ years & 64 & 3,05 & 0,50 & & \\
\hline & More than 16 years & 65 & 3,07 & 0,48 & & \\
\hline \multirow[t]{4}{*}{ Affordances } & $1-3$ years & 11 & 3,91 & 0,66 & 1,029 & 0,381 \\
\hline & $4-10$ years & 73 & 3,53 & 0,71 & & \\
\hline & 11-16 years & 64 & 3,70 & 0,86 & & \\
\hline & More than 16 years & 65 & 3,65 & 0,83 & & \\
\hline \multirow[t]{4}{*}{ Institutional Support } & $1-3$ years & 11 & 3,41 & 0,96 & 0,403 & 0,751 \\
\hline & $4-10$ years & 73 & 3,33 & 0,84 & & \\
\hline & 11-16 years & 64 & 3,42 & 0,79 & & \\
\hline & More than 16 years & 65 & 3,26 & 0,98 & & \\
\hline \multirow[t]{2}{*}{ Student to Student Interaction } & $1-3$ years & 11 & 2,84 & 0,56 & 1,201 & 0,311 \\
\hline & $4-10$ years & 73 & 2,94 & 0,81 & & \\
\hline
\end{tabular}




\begin{tabular}{|c|c|c|c|c|c|c|}
\hline & 11-16 years & 64 & 2,87 & 0,68 & & \\
\hline & More than 16 years & 65 & 3,10 & 0,79 & & \\
\hline \multirow[t]{4}{*}{ Course Design } & $1-3$ years & 11 & 3,60 & 0,56 & 0,884 & 0,45 \\
\hline & $4-10$ years & 73 & 3,56 & 0,52 & & \\
\hline & 11-16 years & 64 & 3,54 & 0,57 & & \\
\hline & More than 16 years & 65 & 3,69 & 0,68 & & \\
\hline \multirow[t]{4}{*}{ OISM } & 1-3 years & 11 & 3,30 & 0,46 & 0,491 & 0,689 \\
\hline & $4-10$ years & 73 & 3,24 & 0,47 & & \\
\hline & $11-16$ years & 64 & 3,31 & 0,52 & & \\
\hline & More than 16 years & 65 & 3,34 & 0,55 & & \\
\hline
\end{tabular}

A one-way ANOVA test was conducted to determine whether the participants' levels of satisfaction differed according to years of teaching English face-to-face and online teaching $(p>05)$. The results of the one-way ANOVA test revealed that there was not any statistically significant difference between participants according to their years of experience and their satisfaction levels in Instructor to Student Interaction, Affordances, Institutional Support, Student to Student Interaction, Course Design, and OISM ( $\mathrm{p}>05)$.

Table 4. The highest educational degree and online instructor job satisfaction

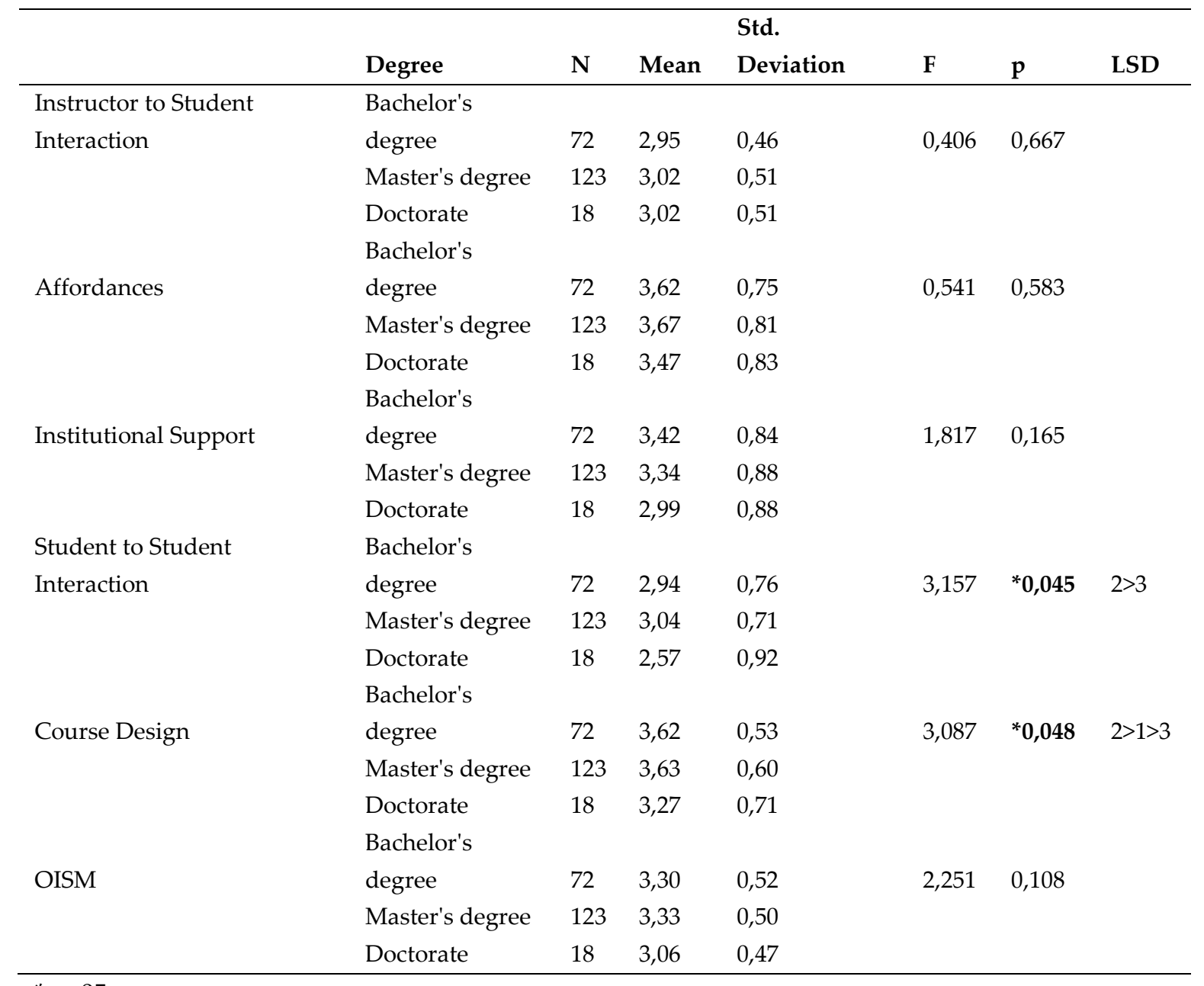

${ }^{*} \mathrm{p}<.05$ 
The difference in "Student to Student Interaction" was statistically significant ( $F=3.16$, $\mathrm{p}=.04, \mathrm{p}<.05)$. The participants who had a doctorate had a higher rating in Student-to-Student Interaction. Also, there was a statistically significant difference in Course Design based on the educational status of the participants $(\mathrm{F}=3.09, \mathrm{p}=.04, \mathrm{p}<.05)$. The participants with a master's level of education had higher ratings than the participants with a bachelor's and doctorate in satisfaction with Course Design related factors.

The mean score of the participants with the bachelor's degree was 2.94 in student-tostudent interaction satisfaction level. The Student-to-Student Interaction satisfaction level of participants with a master's degree was 3.04, while the mean score of the participants with a doctorate was 2.57. According to the results, the differentiation came from the participants at the graduate education level and the participants at the doctoral education level. Considering the arithmetic averages, it was determined that the participants with a master's degree had a more positive approach relating to Student-to-Student Interaction in terms of job satisfaction than those at the doctoral level.

It was determined that the participants' level of participation in Course Design differed according to their educational status, and it was statistically significant $(\mathrm{F}=3.09, \mathrm{p}=.04, \mathrm{p}<.05)$. The Course Design satisfaction of the participants at the undergraduate education level mean score was 3.62, the graduate education level 3.63, and the doctoral education level is 3.27 .

It can be interpreted that the differentiation arose from the participants with a master's degree. It was determined that the participants at the graduate education level showed a more positive approach to Course Design satisfaction than those with both bachelor's degree and doctorate. In addition, it was seen that the participants with a bachelor's degree exhibited a more positive approach to course satisfaction than those at the doctoral level.

\section{Discussion}

This study aimed to explore instructors' job satisfaction during online education. Instructors' demographics and their professional and educational backgrounds were analyzed accordingly. The results were checked statistically. The demographics were found as the influential factors on instructor job satisfaction. In the same vein, Hagedorn (2000) indicated that demographics such as age, gender, and years of teaching experience were remarkable on job satisfaction. There was a statistically significant difference between female 
and male participants in terms of Instructor-to-Student Interaction. Unlike Topchyan and Woehler (2021), this study found that male participants had a higher score in factors related to the interaction between instructor aspects of job satisfaction. Nonetheless, both of those studies found that the duration of teaching experience was not a determining factor of job satisfaction. In contrast, Arbaugh et al. (2001) concluded that teaching experience was the most influential variable on job satisfaction. Similarly, Howe et al. (2018) investigated the effect of years of face-to-face and online teaching experience, and only online teaching experience was found to influence job satisfaction. In comparison to the present study's findings, that study did not find any correlation between years of teaching experience and instructor job satisfaction, as well. Also, there were significant differences among participants with different highest degrees. There were differences among the participants with additional educational degrees. Participants with a master's degree had the highest mean score in the Student-to-Student Interaction subscale. It can be interpreted that different educational backgrounds impacted job satisfaction from other dimensions. Those findings were consistent with Daryanto's study (2014) on job satisfaction and its relation with career development.

It can be appraised that job satisfaction is a complex notion concerning various factors. For example, interaction during lessons, institutional support, course design, and affordances are subdimensions, and the demographics affect online instructors' job satisfaction. Additionally, online instructor job satisfaction plays a crucial role in reaching a higher quality in online education. Therefore, when instructors' perspectives, professional fulfillment, and expectations are ignored, achieving total success for institutions and learners in online teaching would not be possible. Since online education has become very common because of the ongoing situations worldwide, new regulations can be planned to increase the job satisfaction of online instructors.

\section{Limitations and Implications}

This study has a relatively small group of target participants. Even though several emails were sent to the instructors, only a limited number of instructors responded; therefore, the sample may not be generalized for some points. The other limitation is the pandemic. The unexpected ongoing health issues are serious, and participants might have some difficulties in their personal lives, and they might not show their actual job satisfaction level. 
Since instructor job satisfaction consists of internal and external factors, institutions can offer some regulations and improvements to support. Similar to Bolliger et al. (2014), this study also suggests that instructors should be supported for professional development, specifically for increasing student-to-instructor and instructor-to-instructor interaction patterns.

Future Research

Job satisfaction, especially online instructor job satisfaction, is not a common topic in EFL research. Considering the complexity of instructor job satisfaction and online education in English language teaching, further research can be conducted to improve the quality of online language teaching and reach higher levels of online teaching satisfaction.

Ethics Committee Permit Information

Name of the board that carries out the ethical evaluation: Yaldiz Technical University Ethics Committee

The date of the ethical assessment decision: 24.06.2021

Ethical assessment document number: 2021/04

Author Contribution Statement

Esra ECE: Conceptualization, literature review, data collection, data analysis and editing.

Semin KAZAZOĞLU: Conceptualization, design of methodology, data interpretation, consultancy and review writing.

\section{References}

Arbaugh, J. B. (2001). How instructor immediacy behaviors affect student satisfaction and learning in web-based courses. Business Communication Quarterly, 64(4), 42-54.

Berbegal-Mirabent, J., Mas-Machuca, M., \& Marimon, F. (2018). Is research mediating the relationship between teaching experience and student satisfaction? Studies in Higher Education, 43(6), 973-988.

Bogg, J., \& Cooper, C. L. (1994). An examination of gender differences for job satisfaction, mental health, and occupational stress among senior UK civil servants. International Journal of Stress Management, 1(2), 159-172.

Bogler, R. (2005). Satisfaction of Jewish and Arab teachers in Israel. The Journal of Social Psychology, 145(1), 19-34.

Bolliger, D. U., Inan, F. A., \& Wasilik, O. (2014). Development and validation of the online instructor satisfaction measure (OISM). Educational Technology $\mathcal{E}$ Society, 17(2),183-195.

Bozkurt, A., \& Sharma, R. C. (2020). Emergency remote teaching in a time of global crisis due to CoronaVirus pandemic. Asian Journal of Distance Education, 15(1), 1-6 
Bullers, S. (1999). Selection effects in the relationship between women's work/family status and perceived control. Family Relations, 181-188.

Chamberlain, S. A., Hoben, M., Squires, J. E., \& Estabrooks, C. A. (2016). Individual and organizational predictors of health care aide job satisfaction in long term care. BMC Health Services Research, 16(1), 1-9.

Creswell, J.W. (2014). Research design: Qualitative, quantitative, and mixed methods approaches, London: Sage publications.

Daryanto, E. (2014). Individual characteristics, job characteristics, and career development: a study on vocational school teachers' satisfaction in Indonesia. American Journal of Educational Research, 2(8), 698-702. https://doi.org/10.12691/education-2-8-20.

Dodd-McCue, D., \& Wright, G. B. (1996). Men, women, and attitudinal commitment: The effects of workplace experiences and socialization. Human relations, 49(8), 1065-1091.

Gall, M. D., Gall, P. J., \& Borg, W. R. (2007). Educational research: An introduction. Boston: Pearson Education, Inc.

Gay, G. H. (2016). An assessment of online instructor e-learning readiness before, during, and after course delivery. Journal of Computing in Higher Education, 28(2), 199-220.

Gazza, E. A. (2017). The experience of teaching online in nursing education. Journal of Nursing Education, 56(6), 343-349.

Guo, S., \& Hussey, D. L. (2004). Nonprobability sampling in social work research: Dilemmas, consequences, and strategies. Journal of Social Service Research, 30(3), 1-18.

Hagedorn, L. S. (2000). Conceptualizing faculty job satisfaction: Components, theories, and outcomes. New Directions for Institutional Research, 27(1), 5-20.

Hardianto, H., Rugaiyah, R. \& Rosyidi, U. (2019). The effect of reward and job satisfaction toward turnover intention of private junior high school teachers. International eJournal of Educational Studies (IEJES), 3 (6), 128-140. DOI: 10.31458/iejes.544742.

Herzberg, F. (1987). One more time: How do you motivate employees? Harvard Business Review, 65(5), 109-120. http://dx.doi.org/10.1007/978-1-349-02701-9_2

Herzberg, F., Maunser, B. \& Snyderman, B. (1959). The motivation to work, New York, NY: John Wiley and Sons Inc.

Hongying, S. (2007). Literature review of teacher job satisfaction. Chinese Education \& Society, 40(5), 11-16.

Howe, D. L., Chen, H. C., Heitner, K. L., \& Morgan, S. A. (2018). Differences in nursing faculty satisfaction teaching online: A comparative descriptive study. Journal of Nursing Education, 57(9), 536-543.

IBM Corp. Released. (2017). IBM SPSS statistics for windows, version 25.0. Armonk, NY: IBM Corp.

Kennedy, A. M. (2015). Faculty perceptions of the usefulness of and participation in professional development for online teaching: An analysis of faculty development and online teaching satisfaction. University of Wyoming.

Kentnor, H. E. (2015). Distance education and the evolution of online learning in the United States. Curriculum and Teaching Dialogue, 17(1), 21-34. 
Kuo, Y. C., Walker, A. E., Belland, B. R., Schroder, K. E., \& Kuo, Y. T. (2014). A case study of integrating Interwise: Interaction, internet self-efficacy, and satisfaction in synchronous online learning environments. International Review of Research in Open and Distributed Learning, 15(1), 161-181.

Murray, J. P., \& Cunningham, S. (2004). New rural community college faculty members and job satisfaction. Community College Review, 32(2), 19-38.

Reilly, J. R., Gallagher-Lepak, S., \& Killion, C. (2012). Me and my computer: emotional factors in online learning. Nursing Education Perspectives, 33(2), 100-105.

Ripki, A., Murni, S., \& Wahyudi, M. (2020). Creative thinking of vocational high school teachers: effects of transformational leadership and job satisfaction. International eJournal of Educational Studies (IEJES), 4 (7), 93-105. DOI: 10.31458/iejes.608021.

Sanje, G., \& Varnali, K. (2014). The effects of teaching style and internet self-efficacy on instructors' attitudes toward online education in higher education. American International Journal of Contemporary Research, 4(7), 35-43.

Sloan Consortium. (2002). Quick guide: Pillar reference manual. Needham, MA: Author. Retrieved August 28, 2021, from http://www.sloanc.org/publications/books/dprm_sm.pdf

Smedley, J. K. (2010). Modelling the impact of knowledge management using technology. OR Insight, 23, 233-250. DOI:10.1057/ori.2010.11.

Thompson, D. P., McNamara, J. F., \& Hoyle, J. R. (1997). Job satisfaction in educational organizations: A synthesis of research findings. Educational Administration Quarterly, 33(1), 7-37.

Topchyan, R., \& Woehler, C. (2021). Do teacher status, gender, and years of teaching experience impact job satisfaction and work engagement?. Education and Urban Society, 53(2), 119-145.

Ulmer, L.W., Watson, L.W., \& Derby, D. (2007). Perceptions of higher education faculty members on the value of distance education. The Quarterly Review of Distance Education, 8(1), 59-70.

World Health Organization. Coronavirus disease (COVID-19) outbreak. Available from: https://www.who.int/emergencies/diseases/novel-coronavirus-2019. Accessed 15 Feb 2020.

JCER's Publication Ethics and Publication Malpractice Statement are based, in large part, on the guidelines and standards developed by the Committee on Publication Ethics (COPE). This article is available under Creative Commons CC-BY 4.0 license (https://creativecommons.org/licenses/by/4.0/) 